This work is licensed under a Creative Commons Attribution 4.0 International License. Ovaj rad dostupan je za upotrebu pod licencom Creative Commons Imenovanje 4.0 međunarodna.

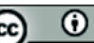

Ugo VLAISAVLJEVIĆ

UDK 1:159.964.2

Filozofski fakultet

DOI: https://doi.org/10.29162/ANAFORA.v7i2.1

Univerzitet u Sarajevu

Franje Račkog 1

Izvorni znanstveni članak

$\mathrm{BiH}-71000$ Sarajevo

Original Research Article

vlaisugo5@gmail.com

Primljeno 2. listopada 2020.

Received: 2 October 2020

Prihvaćeno 20. prosinca 2020.

Accepted: 20 December 2020

\title{
S ONU STRANU OKRUTNOSTI. OPASNI PRIJATELJ ZASTRAŠUJUĆE PSIHOANALIZE
}

\section{Sažetak}

U ovom radu predlažemo izvjesno 'čitanje izbliza’ izlaganja koje je Jacques Derrida imao na međunarodnom skupu psihoanalitičara, koji je pod naslovom Les États généraux de Psychanalyse održan u srpnju 2000. godine. Slaveći stogodišnjicu objave Freudova Tumačenja snova, ovaj reprezentativni skup upriličen je pod okriljem 'političke metafore' sugerirane njegovim povijesno bremenitim naslovom i datumima održavanja. U Derridainu obraćanju metafora revolucije bila je mnogo više nego tek blještavi amblem skupa koji izražava volju organizatora da se naglasi revolucionarni karakter Freudova 'izuma' ili da se pobudi entuzijazam sudionika za rješavanje aktualne krize njihove profesije po uzoru na Opće staleže iz 1789. godine. Tek je u svome kasnom radu, a posebice u ovom uvodnom predavanju posvećenom ljudskoj okrutnosti i njezinim novijim povijesnim preobrazbama, Derrida počeo istraživati dekonstruktivne političke potencijale psihoanalize. Njegova hipoteza o nadmoći psihoanalize nad svim drugim diskursima u bavljenju ovim nadasve političkim pitanjem pretpostavlja da postoji, iako još ne sasvim priznata ili čak izložena velikim otporima, politika inherentna Freudovoj teoriji. Naznačena u njegovim kasnim spisima, Freudova 'progresivna politika', već angažirana u podrivanju principa držav- 
nog suvereniteta, budući da se pokazala sposobnom da ukaže na strategiju prolaska 's onu stranu nagona smrti', poziva na stvaranje nove revolucionarne psihoanalize s onu stranu svih principa. U ovom će radu posebno biti važno iznijeti na vidjelo da Derridaino politički usmjereno čitanje Freudove ostavštine bitno ovisi o njegovoj posebnoj i jedinstvenoj poziciji „prijatelja psihoanalize“.

Ključne riječi: okrutnost, prijatelj psihoanalize, nagon smrti, princip suvereniteta, revolucija

\section{Uvod}

Jacques Derrida imao je čast biti uvodničar, jedan od dvojice „posebno pozvanih“, na velikom međunarodnom kongresu psihoanalitičara, koji je pod nazivom Les États généraux de Psychanalyse održan od 8. do 11. srpnja 2000. godine u Velikom amfiteatru Sorbone. Trebalo je obilježiti stogodišnjicu psihoanalize, a toliko je bilo prošlo od objavljivanja Freudova Tumačenja snova. No, već iz naslova skupa, a također i iz datuma njegova održavanja, mogla se očitati i namjera obilježavanja drugog velikog događaja za koji se ne očekuje da ga slave psihoanalitičari, barem ne kao važnu prekretnicu u povijesti psihoanalize. Godina nastanka psihoanalize tako je našla svoj duboki povijesni eho s čuvenim sazivom općih ili državnih staleža koji su se 9. srpnja 1789. proglasili Narodnom ustavotvornom skupštinom. Vezivanjem utemeljenja znanosti o nesvjesnom $\mathrm{s}$ datumom početka Francuske revolucije možda se htjelo ukazati na revolucionarnost Freudove psihoanalize. Međutim, takvo vezivanje podrazumijevalo bi da se u Freudovu učenju vidi ne samo znanstvena nego i politička revolucija.

Ako za prvi, epistemološki smisao revolucije očekujemo da je psihoanalitičarima uglavnom samorazumljiv i da među njima o tome nema nikakvih bitnih razmimoilaženja, jer je to konsenzus koji se tiče vlastitog staleškog položaja i interesa, to nije slučaj, lako je pretpostaviti, s drugim izrazito političkim smislom revolucije. ${ }^{1}$ Nipošto nije izvjesno da na psihoanalizu tako gleda većina psihoanalitičara.

Ako je već naslov skupa sugerirao da su suvremeni „opći uvjeti ili stanja psihoanalize“ takvi da ih treba razmatrati u bremenitoj povijesnoj konotaciji

\footnotetext{
${ }^{1}$ Međutim, sasvim je drugo pitanje kako se razumijeva znanstveni smisao Freudove revolucionarnosti, koja se obično tumači kao svojevrsna „Kopernikanska revolucija“. O kolebanjima već kod samoga Freuda i njegovim vlastitim otporima prema ovoj revoluciji, Laplanche je iznio podrobnu analizu (53-85).
} 
urgentnog sazivanja „općih staleža“, onda je revolucionarnost psihoanalize ili njezin napokon politički obrat tek ono što se očekivalo od ovog skupa. U prvom pozivu koji je inicijator i glavni organizator skupa, psihoanalitičar René Major poslao još u lipnju 1997. godine predloženi se naslov skupa objašnjava kao obvezujuća „povijesna referenca“.2 Naslov je trebao biti ponajprije shvaćen kao „referenca na Revoluciju, na pokušaj demokratiziranja govorenja i glasovanja, ali i zato što su se u po svome nastanku ovi Staleži održavali u razdoblju krize“ (Décarie 49).

Stogodišnjica psihoanalize nije, dakle, shvaćena kao razlog za slavlje, nego kao povod za odlučan demokratski, čak revolucionarni angažman cjelokupne analitičke zajednice pred dubokom krizom koja ju je zahvatila. Prema Philippeu Lacouru, naslov skupa, koji je kasnije René Major prenio u naslov objavljenih priloga, treba čitati kao metaforu koja ima povijesni politički smisao, prije svega zato što ukazuje na duboku krizu. Ta metafora podrazumijeva „želju za uspostavljanjem (stvaranjem neke ustanove) i ukinućem privilegija (nadređenosti izvjesnih ustanova); ali je razlika s 1789. godinom što nema kralja (otuda decentrirana organizacija)“ (Lacour 120).

Ako je ta metafora lebdjela nad impresivnim međunarodnim skupom, koji je okupio više od tisuću i dvjesto psihoanalitičara iz trideset i četiri zemlje, tko je u ime organizatora ili u ime sudionika skupa mogao i trebao položiti račun o takvom povijesno-političkom povezivanju koje se moglo činiti kao motivirajuće psihoanalitičko komemoriranje početka Francuske revolucije? Što je to moglo osigurati tom metaforom naznačenu transpoziciju iz okvira uobičajenih tema kakve očekujemo od reprezentativnog okupljanja jednog „profesionalnog staleža“: „diskusije o aktualnom stanju psihoanalize“, „propitivanje institucionalnih modela obučavanja, obrazovanja i prenošenja“, kritičko osvrtanje na postojeće institucionalne okvire i prakse, traženje novih modela koji odgovaraju „bitno inovativnom, čak subverzivnom psihoanalitičkom načinu postupanja“ itd. (Huber 7)?

Moglo je, dakako, sve ostati na izvanjskoj poveznici jedne blještave metafore, na suptilnoj naznaci dubljeg povijesnog smisla obilježavanja stogodišnjice

\footnotetext{
2 Tamo čitamo: „Ako ovaj poziv uzima ime 'Općih staleža' (Etats Généraux) da bi se preispitalo ono što se činilo do sada, što se čini još i danas, a činit će se i sutra, u ime psihoanalize ili pod njezinim imenom, to je upravo stoga da se može očekivati, u ime povijesne reference naznačene ovim imenovanjem, da je uspostavljen novi zahtjev koji ne drži do hijerarhijskog zapovijedanja nego do želje i odluke učesnika“" (Major, Appel pour les États Généraux).
} 
rođenja psihoanalize, pri čemu je trebalo pobuditi ne samo svijest o dubokoj krizi psihoanalize, što su kasnije potvrdila brojna izlaganja baveći se višestrukim aspektima te krize, nego i o još nerealiziranom revolucionarnom kapacitetu psihoanalize, onog koji bi ukazivao na mogućnosti radikalnog političkog, društvenog, ekonomskog, etičkog, pravnog (itd.) obrata. Obrata $u$ psihoanalizi i obrata u svijetu izvan psihoanalize, a zahvaljujući njoj. No, ostalo je upitno može li jedan „stalež“ tako nešto uopće poduzeti, najprije u svojim redovima, a kamoli druge „staleže“ oko toga angažirati.

\section{Prijatelj psihoanalize}

Ne prekoračuju li se metaforom, koja otvara nesagledive (povijesne, etičke, pravne, ekonomske itd.) dubine aktualno političkog, daleko izvan granica psihoanalize i mogu li za to psihoanalitičari uopće biti pozvani? Nije li to onda najradikalniji zahtjev za propitivanjem samih granica psihoanalize ili, drugim riječima, krajnje prijeporan poziv da se ponovo položi račun o tome što je psihoanaliza? Ako je trebalo osvijetliti revolucionarnost psihoanalize koja se tiče suvremene povijesti svijeta, nije li metaforom naznačeno povezivanje za samu psihoanalizu u bitnom smislu izvanjsko? Ne traži li ono ne samo jedan pogled izvan psihoanalize, nego također i pogled izvana na psihoanalizu?

Ako je pogled izvana kojim bi se dohvatilo ono političko iznutra bio svojevrsni nalog „povijesne reference“ iz naziva skupa, onda ne iznenađuje da je René Major za konferansjee pozvao Derridau i čileanskog pisca i pravnika Armanda Uribea koji je nastupio kao specijalist za diktaturu Augusta Pinocheta. Isabelle Décarie ovako objašnjava njihovu pozvanost da otvore skup:

Ova dva intelektualca održavaju bliske veze s psihoanalizom izvana i predstavili su, dakle, svoje gledište o aktualnom stanju psihoanalize polazeći od prava, filozofije, pisanja i toliko drugih scena s kojih oni govore o psihoanalizi na način koji možda ne izgleda sasvim 'legitiman' i 'ovlašten', ali zato nije manje plodan (ponekad je i plodniji). (Décarie 48-49)

Međutim, ako je prema upravo ocrtanoj topografiji sve to bilo moguće postići samo polazeći od onog izvana koje je usko povezano s onim iznutra, jedino se Derrida odvažio pokazati da su „unutarnje stvari“ psihoanalize političke u emfatičkom smislu i da se ono političko suvremenog svijeta ne može odgonetnuti u svojoj biti bez psihoanalize. Time što je pokušao dokazati politički karakter psihoanalitičke revolucije, njegovo uvodno izlaganje trebalo je učiniti 
uvjerljivom i legitimnom povijesnu referencu iz naziva skupa, mada je osim nekoliko naznaka odustao od povlačenja povijesne analogije između dva „staleška“" okupljanja. ${ }^{3}$ Ako se Derrida jedini mogao odvažiti da pruži takvu vrstu legitimiteta velikom međunarodnom skupu psihoanalitičara i u stvari bio pozvan da to učini, to je prije svega zato što je u svojoj karijeri filozofa gajio „bliske veze s psihoanalizom. “ Čini se da to nije mogao izvesti netko drugi od brojnih sudionika, od onih koji imaju puni „legitimitet i autorizaciju“ psihoanalitičara. Mogli bismo reći da je to ovaj francuski filozof učinio kao „prijatelj psihoanalize“, s pozicije koju je još Sándor Ferenczi legitimirao svojom idejom o „Društvu

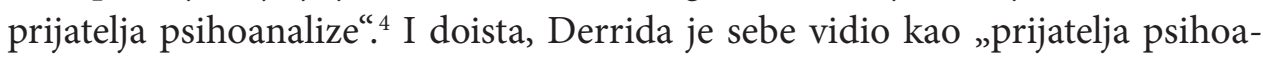
nalize“, kako je to potvrdio u jednom razgovoru s Elisabethom Roudinesco, ali pritom ne smijemo previdjeti njegovu naročitu blizinu psihoanalizi iz koje je definirao vrstu i način toga svog prijateljevanja.

Volim izraz 'prijatelj psihoanalize'. On govori o slobodi jednog saveza, angažmanu bez institucionalnog statusa. Prijatelj ima uzdržanost ili povučenost, neophodne za kritiku, raspravu, međusobno ispitivanje, ponekad ono najradikalnije. (...) Prijatelj je onaj koji odobrava, podržava, potvrđuje neizbrisivu nužnost psihoanalize, a to prije svega znači ono što od nje tek treba doći, ali koji se također zanima i za ono što je kod nje problematično, ponekad vještačko, umjetno, dakle podložno dekonstrukciji. (Derrida, Roudinesco 271-73)

Prijatelj psihoanalize, kako sebe Derrida razumijeva, nipošto nije onaj prijatelj kako ga je Ferenczi vidio: neosposobljen, neovlašten, interesent kojeg treba držati dovoljno daleko i od same institucije i od članstva, od kojeg se može očekivati samo javna podrška stvari psihoanalize ili pak nepoželjno bavljenje „div-

\footnotetext{
3 „Najprije sam bio u iskušenju, a potom sam morao, u nedostatku vremena, oduprijeti se tom iskušenju da odem suviše daleko u komparativnoj analizi États généraux iz 1979. i États généraux psihoanalize" (Derrida, États d'âme de la psychanalyse 25).

${ }^{4}$ U svome pismu Freudu od 10. kolovoza 1925. godine, u doba kada je trebao pripremati naredni kongres psihoanalitičara, Ferenczi, između ostalog, piše: „Pisani dio rada na Kongresu nisam još započeo, ali o tome već imam gotovo završen plan u glavi. Pored toga bih na Kongresu pokrenuo nešto što ne bi smjelo, kako vjerujem, biti nevažno, i sa stanovišta budućnosti psihoanalize i sa stanovišta nakladništva. Predložit ću osnivanje 'Međunarodnog društva prijatelja psihoanalize' s mnogim gradskim filijalama, za čije članstvo ne bi trebala biti vezana nikakva posebna osposobljenost. Svrha osnivanja bi bila: povoljan utjecaj na 'divlje' psihoanalitičare i interesente. (...) Skupovi 'prijatelja' bi morali biti i prostorno i vremenski sasvim odvojeni od naših kongresa, a kruta organizacija naših udruga i stroga cenzura njihovog članstva bi, dakako, prije svega bila održana" (Freud, Ferenczi 47-48).
} 
ljom psihoanalizom“. Upravo nas Derridain izuzetan psihoanalitički angažman uči da nisu svi prijatelji psihoanalize isti, da nisu svi članovi istog „društva“.

Derridaino „izvan“ nije ona pretpostavljena nekompetentnost i neupućenost Ferenczijevih prijatelja psihoanalize. Novi smisao prijateljstva, po kojem bi mislilac dekonstrukcije možda bio jedini i izniman, ukazuje na veliku blizinu psihoanalizi, na izuzetno blisko prijateljstvo. Kako pojašnjava Elizabeth Rottenberg, Derridaino prihvaćanje "plašta prijatelja psihoanalize“ podrazumijeva distanciranje od Ferenczijeve koncepcije te „posebnu i prilično neobičnu blizinu psihoanalizi“ ${ }^{5}$ Međutim, Derridaino izjašnjenje kao „prijatelja psihoanalize“ također traži navodnike nad tom oznakom da bi se ukazalo na neobičnu blizinu koja ne uklanja distanciranost. Naprotiv, ona ju neizostavno pretpostavlja. ${ }^{6}$

Osim Derridainih izjašnjavanja o svome odnosu prema psihoanalizi, kojima je od početka pa do kraja markiran njegov mislilački put, važno je i to kako je ovaj „prijatelj“ viđen i iz samih krugova psihoanalitičara. Ovo drugo je barem važnije u slučaju Derridaina uvodnog izlaganja na skupu povodom jednog stoljeća psihoanalize, a za to je najpozvaniji upravo onaj koji ga je na taj skup i pozvao. René Major predstavlja vezu Derridae i psihoanalize ne samo izuzetno bliskom nego i nerazlučivom:

... niti bi bilo, a niti ima Derridae bez Freuda. A zauzvrat, putevi prokrčeni deridijanskim čitanjima Freudovog djela i Lacanovog djela su postali putevi koje psihoanaliza ne bi smjela zaboraviti ili sebi uskratiti. Osim pod prijetnjom da samu sebe zaboravi. (Major, Derrida, lecteur de Freud et de Lacan 167)

\footnotetext{
${ }^{5}$ Nabrajajući desetine Deridainih ogleda i knjiga u kojima se izravno bavio psihoanalizom, Rottenberg će istaknuti da je „od svog posve prvog ogleda o Freudu koji je predstavljen u ožujku 1966. godine pri Pariškom psihoanalitičkom društvu, na poziv André Greena, pa do uvodnog obraćanja Međunarodnoj psihoanalitičkoj udruzi (IPA) na États généraux psihoanalize u srpnju 2000. godine u Velikom amfiteatru Sorbone, Jacques Derrida izgleda oduvijek bio takav 'prijatelj psihoanalize"“ (Rottenberg, Derrida and Psychoanalysis 305).

${ }^{6}$ Ponajprije je u pravu Geoffrey Bennington koji „složene odnose između Derridae i psihoanalize“ sabire pod nazivom „problematična blizina“ (94). U svom uvodnom predavanju na Francusko-latinsko-američkom susretu psihoanalitičara dvadeset godina ranije, također upriličenom na poziv Renéa Majora, Derrida će na gotovo provokativan način istaknuti svoju autsajdersku poziciju, poistovjećujući se sa „stranim tijelom" u globalnoj zajednici psihoanalitičara, koje poput simptoma - a ovaj će uvodničar podsjetiti skup da Freud na jednom mjestu simptom određuje kao strano tijelo (Fremdkörper) - „ne može biti ni asimilirano ni odbačeno, ni interiorizirano ni, na granici crte dje-
} ljive između onog unutra i onog vani, potpuno isključeno" (Derrida, Psyché 330). 
Ako je već trebalo ukazati na izuzetnu i neobičnu bliskost ovog francuskog filozofa i psihoanalize, Major se nije kolebao da ide čak dotle da ustvrdi da se radi o „prvobitnoj vezi, kao s materinjim jezikom“ (Major, Derrida, lecteur de Freud et de Lacan 167). Znači li to vjerovati da bi trebalo ukinuti svaku distancu između deridijanskog diskursa i psihoanalitičkog diskursa? Što onda, dakako, više ne bi ostavilo nikakve distance neophodne za status „prijatelja psihoanalize“. No, da i tu, u tako snažnoj bliskosti, ima mjesta za ono što bismo mogli nazvati „prijateljskom udaljenošću“ ili „distancom prijatelja“, o tome sam Derrida pruža svoje tumačenje ili, radije, priznanje, pod uvjetom da, prema Majorovoj sugestiji, njegov odnos prema materinskom jeziku shvatimo kao njegov odnos prema psihoanalizi.

U knjizi u čijem podnaslovu stoji da je to Posljednji intervju čitamo, između ostalog, o Derridainoj „nevjernoj vjernosti“ prema francuskom jeziku (Derrida, Learning to Live Finally 36). U takav odnos prema materinskom jeziku može se čak upisati distanca jednog istinskog stranca, kakvim se mogao osjećati Derrida kao alžirski Židov spram „rođenog Francuza“, a mi tog potonjeg, u usporedbi do koje nam je ovdje stalo, možemo uzeti i kao figuru „legitimnog i ovlaštenog psihoanalitičara“:

Vjerujem da ako volim ovaj jezik kao što volim svoj život, a ponekad i više nego neki rođeni Francuz, to je stoga što ga volim kao stranac koji je srdačno dočekan i koji je sebi prisvojio ovaj jezik kao za njega jedino mogući. Strast i hiperbolizacija. (Derrida, Learning to Live Finally 37)

Ali to što je „prisvojio ovaj jezik“ i što „ima samo jedan jezik“, požurit će Derrida pojasniti, ne znači da mu ovaj doista i pripada. Nema dvojbe da je Derrida stanac - filozof koji je srdačno dočekan, barem u nekim psihoanalitičkim krugovima, kao što je ne manje izvjesno da je „sebi prisvojio ovaj jezik“, dodajmo, psihoanalize - doduše ne kao „za njega jedini mogući“, ali opet jamačno sa „strašću i hiperbolizacijom“ (37).

U Derridainu strast mogao se uvjeriti svatko tko je pročitao makar jedan njegov ogled o psihoanalizi, kao što se ne može osporiti da je stalno ukazivao, bilo izričito ili prešutno, da treba slijediti Freuda u njegovim hiperbolizacijama, što će reći ići sve dalje i „s onu stranu“, sukladno onoj poznatoj Adornovoj opasci da „u psihoanalizi ništa nije istinito osim njenih pretjerivanja“ (56). 
U stvari, neobična i specifična, samo Derridaina pozicija „prijatelja psihoanalize" nije ništa drugo doli neophodna pozicija onog tko se odlučuje na dekonstrukciju izvjesne teorije, učenja, filozofema, epistomema. Ako se od posljednjeg intervjua premjestimo na sam početak Derridaine karijere, vidjet ćemo da je u svom prvom intervjuu objavljenom 1967. godine Derrida strategiju dekonstruktivističkog čitanja vezao uz „pisanje s dvije ruke“, uz double jeu, uz „ujedno vjerno i nasilno kruženje između onog što je unutra i onog što je izvana filozofije - tj. Zapada“. Tamo u jednom od Derridainih odgovora saznajemo da novi način filozofskog promišljanja pretpostavlja analizu potiskivanja, kao i vraćanja potisnutog kroz simptome:

'Dekonstruirati' filozofiju bi stoga bilo promišljati strukturiranu genealogiju njenih pojmova na najvjerniji, najunutarnji način, ali istovremeno polazeći od izvjesnog izvana koje ona nije u stanju odrediti, imenovati, odrediti ono što je ta povijest mogla prikriti ili zabraniti, bivajući poviješću putem tog ponegdje koristoljubivog potiskivanja. (Derrida, Positions 14-15)

Pokazuje se da je razlika unutarnje/izvanjsko - ali u njezinoj usukanosti poput Möbiusove vrpce - koja određuje mjesto i status "prijatelja psihoanalize“, ovdje predstavljena kao preduvjet novog načina čitanja temeljnih djela zapadnjačke povijesti. Kako primjećuje Major, već je od prvog Derridaina predavanja o Freudovu magičnom bloku „postalo jasno da mišljenje dekonstrukcije ne ide bez uzimanja u razmatranje onoga što psihoanaliza poziva da se misli. ${ }^{\text {"7 }}$

Takav „prijatelj psihoanalize“ u stanju je biti čak više „unutra“ od onih koji su pozvani da govore u ime psihoanalize, dakle u samom polju psihoanalitičkih istraživanja držati se pravila poretka frojdovskog diskursa, ali i biti „izvan“ tog polja i to ne bilo gdje, nego tamo odakle se tek utvrđuju mogućnosti i granice tog polja. To istovremeno biti „unutra“ i „vani“, u „unutarnjoj izvanjskosti“ i „vanjskoj unutarnjosti“, znači, u stvari, držati se granica psihoanalize, onako kako Derrida opisuje svoje dekonstruktivističko držanje prema filozofskom

\footnotetext{
7 „Nedugo kasnije (nakon prvog susreta i međusobnog upoznavanja), prisustvovao sam čuvenom predavanju koje je Jacques održao na Institutu za psihoanalizu: 'Freud i scena pisanja', nakon kojeg je postalo jasno da mišljenje dekonstrukcije ne ide bez uzimanja u razmatranje onoga što psihoanaliza poziva da se misli, a što se ne iscrpljuje ni u metafizici ni u znanosti pisma (écriture) inherentnog govoru i, obratno, da bi psihoanaliza trebala uvažiti dosege dekonstrukcije logocentrizma, izvjesne radikalizacije mišljenja traga, nužnosti odupiranja pojmova traga i rAzlike (différance) svim klasičnim pojmovnim opozicijama" (Major, Il aura 28).
} 
diskursu, a što mutatis mutandis vrijedi i za psihoanalitički diskurs. ${ }^{8}$ No, ta se granica stalno premješta i klizi, nije utvrđena i fiksirana, osim u dogmatskom shvaćanju psihoanalize, onom koje vjeruje u jednu psihoanalizu i njezinu „homogenu danost“. 9

Za takvu psihoanalizu Derrida se može ukazati kao „opasan prijatelj“, onaj koji otvoreno radi na njezinoj destrukciji (Birnbaum). Ili, ako se od tobože jasno postavljene vanjske granice psihoanalize mjeri pozicija prijatelja, onda se taj filozof, usprkos svojim izjašnjavanjima, pojavljuje kao „ipak prilično daleki prijatelj“ ${ }^{10}$ I doista, ne samo za dogmatski orijentirane sljedbenike Freuda, mogu izgledati uznemirujućim, skandaloznim, čak jasnim očitovanjem „neprijatelja psihoanalize“, neke od Derridainih izjava u kojima on „ukazuje na problematični i dekonstrukciji podložni karakter psihoanalize“, poput:

Možda se varam, ali Ono, Ja, Nad-ja, Ja-ideal, idealno-ja, sekundarni proces i primarni proces potiskivanja itd. - riječju, veliki frojdovski strojevi (uključujući tu pojam i riječ nesvjesnog!) - to su, prema mome mišljenju, samo provizorna oružja, priručna retorička oruđa, protiv filozofije svijesti, transparentne i potpuno odgovorne intencionalnosti. Uopće ne vjerujem u njihovu budućnost. Ne vjerujem da se metapsihologija može na duže vrijeme oduprijeti preispitivanju. $\mathrm{O}$ tome se više gotovo i ne govori. (Derrida, Roudinesco 279-80)

Svi pojmovi psihoanalize trebaju biti podvrgnuti dekonstrukciji, jer svi „redom, bez iznimke, pripadaju povijesti metafizike“, kako to stoji u Derridainu čuvenom predavanju na Institutu za psihoanalizu (Derrida, Freud et la scène de l'écriture 294). Međutim, na uvodnim stranicama knjige O gramatologiji upravo su, pored Heideggerove kritike metafizike i Saussureove lingvistike, psihoanalitičkom istraživanju pripisani „najveći izgledi proširenja prodora“ preko „logocentrične zatvorenosti“ ili „ograda metafizike“ (Derrida, De la Grammatologie 35). Oba ta gledišta pripadaju istom dobu - predavanje je održano svega nekoli-

\footnotetext{
8 „Pokušavam da se držim na granici filozofskog diskursa. (...) Granici, dakle, polazeći od koje je filozofija postala moguća, definirala se kao episteme, funkcionirajući unutar nekog sustava temeljnih prinuda, pojmovnih opozicija izvan kojih ona postaje neizvediva“" (Derrida, Positions 14).

${ }^{9}$ „... upravo ovaj motiv homogenosti, teološki motiv par excellence, treba odlučno uništiti“ (Derrida, Positions 86).

${ }^{10}$ Geneviève Delaisi de Parseval završava s tom kvalifikacijom svoj prikaz knjige De quoi demain: dialogue (16).
} 
ko mjeseci od objavljivanja prve verzije programskog spisa o „općoj gramatologiji“',11 a autor će ih se držati sve do kraja svoga mislilačkog puta.

Sada nam se sama psihoanaliza pojavljuje istovremeno „iznutra“ $i$ „izvana“, s ovu i s onu stranu ograda logocentrične metafizike. Mislilac dekonstrukcije treba prijateljevati s psihoanalizom jer je u stanju dokučiti „ono što od psihoanalize teško može biti zadržano ili obuzdano u logocentričnoj ograđenosti“, ali istovremeno mora biti na oprezu prema „metafizičkim shemama" njezinih pojmova (Derrida, Freud et la scène de lécriture 296). Nezamisliva je kritika metafizike bez psihoanalize, a ništa od same psihoanalize ne smije biti pošteđeno te kritike. Jedan od uvjeta dekonstruktivističke reaproprijacije psihoanalize, bar kako je to predstavljeno u predavanju, jest uvođenje razlike između metafizičkih pojmova psihoanalize, s jedne strane, i frojdovskog diskursa, s druge, koje se u svojoj sintaksi i svome radu opire metafizičkoj pripadnosti. Odvajanje tog diskursa od onoga što mu je najbliže, od vlastitog vokabulara, od „velike pojmovnosti psihoanalize“, $u$ dekonstruktivističkom pisanju markira se navodnicima. ${ }^{12}$ Jedino tako, u otklonu od svoga prvobitnog sadržaja, pojmovi psihoanalize mogu poslužiti kao „provizorna oružja“ u deridijanskoj kritici.

Koliko je frojdovski proboj važan u kritici metafizike može se vidjeti po tome što za Derridu Freud stoji rame uz rame s Heideggerom, kao „dva znamenita duha slavnoga doba" (Derrida, La carte postale 206). U drugom, isto tako veoma utjecajnom predavanju koje je Derrida održao 1968. godine u Francuskom društvu za filozofiju i u kojem je prokrčen put za la différance, navodi iz S onu stranu principa ugode jednako su važni kao i oni iz Bitka i vremena (Derrida, La différance 43-68). Međutim, već će u predavanju u seminaru dr. Greena i to odmah na početku obznaniti: „Usprkos prividima, dekonstrukcija logocentrizma nije psihoanaliza filozofije“ (Derrida, Freud et la scène de lécriture 293). ${ }^{13}$

\footnotetext{
${ }^{11}$ U tom predavanju održanom u ožujku 1966. godine trebalo je, kako čitamo u prvoj uvodnoj napomeni, „otvoriti raspravu o izvjesnim stavovima iznijetim u ranijim ogledima, a posebice u ogledu $O$ gramatologiji“. Derrida tu referira na svoj članak koji je u dva dijela objavljen u časopisu Critique (n 223, décembre 1965, n 224, janvier 1966), a kasnije razrađen i objavljen kao prvi dio knjige (Lécriture avant la lettre) pod istim nazivom.

${ }^{12} \mathrm{U}$ diskursu dekonstrukcije na djelu je „zakon navodnika“: ti parovi znakova poput „štipaljki za veš predstavljaju naznaku moguće suspenzije metafizičke vrijednosti pojmova, neophodnost da „ostaju visjeti u neodlučivosti“" (Derrida, De l’esprit 53).

${ }^{13}$ Očito je imao jakog povoda to učiniti, jer je te "privide“ do tada, a pokazat će se i kasnije, također on sam osnaživao, koristeći se na odlučnim mjestima u svome dekonstruktivističkom čitanju Freudovim pojmovima, poput Verdrängung (refoulement) i Unterdrückung (répression). Cjelokupnu povijest metafizike tumačit će, ne u Heideggerovu terminu „zaborava“, nego u Freudovu terminu
} 


\section{Okrutnost kao politički sadržaj psihičkog}

Ako je jedino Derrida kao jedini „prijatelj psihoanalize“ na sebe preuzeo zadaću da međunarodni skup psihoanalitičara legitimira i makar pokuša angažirati njegove sudionike pod višestoljetnim svodom i povijesno-političkim znamenjem njegova naziva, onda je on u svome izlaganju morao predstaviti sasvim evidentnim i nesumnjivim nešto uistinu političko u samoj psihoanalizi, $\mathrm{u}$ Freudovu nasljeđu, iza čega bi trebao stajati i sam Freudov jasan potpis. Štoviše, budući da je u psihoanalizi oduvijek postojao jak otpor prema njezinu vezivanju uz polje političkog (pa tako i etičkog, pravnog itd.), kao onog što načelno leži izvan njezine domene, a koje opet ovjeravaju jasna Freudova očitovanja, trebalo je pokazati evidentnim ono što nipošto nije bilo evidentno.

Što može biti političko, političko par excellence, psihoanalize? Što je to što bi ju moglo bitno i sudbinski vezati uz društvenu, a ne tek znanstvenu revoluciju, poistovjetiti ju u nekom odlučnom trenutku s revolucijom onog tipa kakva je bila Francuska revolucija (dakle, uz duboki i radikalni društveni, politički, pravni, moralni, ekonomski itd. preobražaj)? Kada Derrida pred kraj svoga izlaganja napominje da bi „psihoanaliza trebala preuzeti svoje odgovornosti, izumjeti ili ponovo izumjeti svoje pravo, svoje institucije, svoje statute, norme itd.“ (i još dodaje: „Pretpostavljam da ste zato ovdje.“) (Derrida, États d'âme de la psychanalyse 86), onda to već može predstavljati dovoljno opravdanje za sazivanje „općih staleža psihoanalize“. Međutim, iz toga se još ne vidi revolucionarni smisao tog povijesnog okupljanja. Zajednice psihoanalitičara, a ima ih mnogo više od jedne, mogu danas afirmirati svoja prava, preuzeti svoje odgovornosti, reformirati svoje institucije, statute i norme, a da ništa političko u emfatičnom smislu ni na koji način ne uđe s ovu stranu granica njihova analitičkog posla. A još manje da nešto iz tako ograničenog polja psihoanalize prodre $u$ vanjski svijet politike.

Međutim, ono što bi trebao biti evidentni politički karakter psihoanalize nije tek stvar društvenog angažmana psihoanalitičara, nije kasnije i naknadno s obzirom na ono čime se oni bave u svome poslu. Nešto psihičko trebalo bi se

„potiskivanja“ - (pra-)pisanja (archi-écriture) ili rAzlike (différance). Pa čak i onda kada tvrdi da „logocentrično suzbijanje nije razumljivo polazeći od frojdovskog pojma potiskivanja“ (Derrida, Freud et la scène de lécriture 294), da je ovo drugo ovisno i izvedeno iz ovog prvog kao uvjeta mogućnosti nastanka i trajanja zapadnjačke kulture, Derrida svoj argument gradi uporabom dva upravo spomenuta Freudova pojma. 
ukazati političkim, a nešto političko, psihičkim. Derrida upravo to nešto iznosi na vidjelo: okrutnost, ljudsku okrutnost kao psihičko nasilje.

Kako definirati tu okrutnost? Možda kao „želju da se drugi pati ili da se sebe pati radi patnje, čak da se muči ili ubija, da samoga sebe ubija ili muči mučenjem i ubijanjem, a sve radi doživljavanja psihičke ugode u zlu radi zla, čak radi uživanja u radikalnom zlu“ (Derrida, États d’âme de la psychanalyse 10)? Kao riječ, okrutnost je bliska svakodnevnom jeziku. Derrida započinje svoje predavanje idiomatskom uporabom glagola, imenice, pridjeva, priloga, odgovarajućih zamjenica i pomoćnih glagola, koji se u francuskom jeziku upisuju u krug onoga što je bio Freudov termin Grausamkeit. Čini se da svatko zna i još nitko točno ne zna „što bi mogla značiti ova strana i bliska, neobična i poznata riječ“ (Derrida, États d'âme de la psychanalyse 11).

Ne treba li od psihoanalize očekivati razjašnjenje smisla riječi i pojma „okrutnost“? Nije li upravo ona pozvana da nam ga pruži, budući da su upravo psihoanalitičari „oni koji od patnje, najokrutnije patnje, prave svoj posao“ (Derrida, États d'âme de la psychanalyse 18)? Nije li jedino psihoanaliza u stanju da se uhvati u koštac s okrutnošću koja je psihička, koja je nezamisliva bez patnje i ugode, bez izvjesnih stanja duše, bez nagona i osjećanja, izvjesnih psihičkih predstava itd.? I doista, Derrida će odmah na početku svoga obraćanja ustvrditi, doduše s velikim oprezom, a to znači iznijeti hipotezu o neiskorjenjivosti okrutnosti u životu čovjeka, i ne samo čovjeka, a na tu hipotezu dodat će hipotezu o pozvanosti i odgovornosti samo jednog diskursa:

Ako ima nešto nesvodivo u životu živoga bića, u duši, u psihi (...) i ako je ta nesvodiva stvar u životu oživotvorenog bića upravo mogućnost okrutnosti (nagon, ako hoćete, za zlom radi zla, za patnjom koja bi se poigravala s time da uživa u paćenju kakvo je kada nekome ili sebi pričinite patnju radi ugode), onda se nijedan drugi diskurs - teološki, metafizički, genetički, fizikalistički, kognivistički itd. - ne bi mogao otvoriti za takvu hipotezu. Svi bi oni bili stvoreni da je reduciraju, isključe, liše smisla. Jedini diskurs koji danas može polagati pravo na stvar psihičke okrutnosti kao na svoj vlastiti predmet bavljenja, to bi bio upravo onaj koji se zove, otprilike jedno stoljeće, psihoanaliza. (Derrida, États d'âme de la psychanalyse 12)

No, sve je još na samome početku. Jedan jedini put, doduše, jest otvoren i to, kako se čini, samo za psihoanalitički diskurs, ali, priznaje Derrida, o nekom 
znanju, pa čak i promišljanju ili razmatranju okrutnosti, jedva da se može govoriti. I nakon stoljeća psihoanalize, sam pojam okrutnosti ostao je „zbrkan i zagonetan, žarište mračnjaštva i u psihoanalizi i izvan nje..." (Derrida, États d’âme de la psychanalyse 21-22). Možda i zato ili upravo zato što se o okrutnosti oduvijek govorilo u religiji i metafizici. A sada kada je to strašno pitanje „patnje radi patnje, činjenja ili dopuštanja zla radi zla“, „radikalnog zla ili zla goreg od radikalnog zla“, prepušteno psihoanalizi, njezino ime postaje ,asocirano uz zlo“ i „sa svoje strane teže za odgonetnuti nego ikada prije“ (Derrida, États d’âme de la psychanalyse 13).

Je li ovaj „prijatelj“ suviše blizu ili suviše daleko psihoanalizi pa da više nije siguran u to što je ona u stvari? Odakle on sada govori? Čini se sa samoga mjesta „stvari okrutnosti“. Može li biti da se samo takvom prijatelju, za kojeg će Geoffrey Bennington s pravom primijetiti da je jedan jedini takav, ${ }^{14}$ moglo dogoditi da na ovaj, posve radikalan način otvori pitanje okrutnosti - kao psihoanalitičko pitanje par excellence? Hoće li biti da je samo jedan jedini „prijatelj“ mogao pokrenuti pitanje okrutnosti s pravoga mjesta, upravo zato što bi ga trebalo tražiti i s onu i s ovu stranu granica psihoanalize? Ali koje psihoanalize, ako ih ima ili bi trebalo biti „više od jedne“ (Derrida, Fidélité à plus d’un)? Možda upravo one koja pokazuje svoje granice - štoviše, nastoji da ih što više utvrdi - pred izazovom „okrutnosti“, kako ga Derrida definira? Dakako, to je ona psihoanaliza koja se pred ovim izazovom ukazuje „u svojim statutarnim i autoriziranim diskursima, tj. u kvazitotalitetu svojih produkcija“ (Derrida, États d’âme de la psychanalyse 22).

Kada je Derrida započeo svoje predavanje uvođenjem razlike između „psihičke okrutnosti“ i „krvave okrutnosti“, doznačujući ovu prvu psihoanalizi, budući da pripada „stanju duše“, djelokrugu psihe, moglo je izgledati da se ništa izvan psihoanalize neće trebati ni spominjati ni tražiti, ništa izvan onoga što se već sasvim dobro i temeljito ne zna o sadizmu, mazohizmu, agresivnosti i slično. Sve što se tiče „hladnog oružja, giljotine, klasičnih i modernih teatara krvavog rata", moglo je, kao i prije, ostati po strani, u najboljem slučaju kao stvar

${ }_{14}$ „Moja hipoteza danas će biti da je Derridain odnos prema psihoanalizi originalan odnos, tj. da je, $s$ jedne strane, ovaj odnos samo njegov (nitko drugi nema takav odnos prema psihoanalizi), i da, s druge strane, nije isti kao oni odnosi koje on održava s drugim autorima ili strujama mišljenja koje čita (...). A također, bez sumnje, da je ovaj Derridain odnos prema Freudu originalan u smislu da je tu već na izvoru, od početka, te da nema i ne bi moglo biti nikakvog Derridae bez Freuda“ (Bennington 96). 
sporadičnog interesa psihoanalitičara i njihovih povremenih izleta u druga područja. Međutim, upravo i jedino psihoanaliza, računajući tu i Freudova preteču Nietzschea, može pokazati ovisnost - kao konstitutivnu psihičku ovisnost - krvave okrutnosti o okrutnosti bez krvi, koja će tu prvu „uvijek snabdijevati izumijevajući nove resurse“ (Derrida, États d’âme de la psychanalyse 10).

Ako suvremenost postavlja neki veliki i uznemirujući izazov pred psihoanalizu, koji ju nipošto ne može ostaviti u njezinim postojećim „staleškim stanjima“, ali ni u njezinim „grizodušjima“, onda je to pitanje okrutnosti u njezinu naizgled vanjskom licu „krvave okrutnosti“. Iza stoljeća psihoanalize, napominje Derrida, stoji „ogromno, bezdano pamćenje“, čitav jedan „svjesni ili nesvjesni arhiv upisan u samu njezinu mogućnost“, najmanje dva stoljeća krvavih revolucija od Francuske pa do boljševičke, svjetskih i lokanih ratova, holokausta, genocida, masovnih deportacija, okrutnosti terora, smrtnih kazni itd. (Derrida, États d'âme de la psychanalyse 62-63). Psihoanaliza je danas suočena, pod uvjetom da okrutnost vidi kao svoju stvar i izvan tzv. analitičke situacije, $s$ „okrutnom preobrazbom okrutnosti“, $s$,tehničkom, znanstvenom, pravnom, etičkom i političkom, i etničkom i vojnom i terorističkom i policijskom preobrazbom“ (Derrida, États d'âme de la psychanalyse 70). Međutim, jednako je istina da se na sve to javljaju pozitivne i ohrabrujuće preobrazbe u odgovarajućim poljima, „kao da je riječ o dva nerazdvojna procesa“, poput utvrđivanja i zaštite ljudskih prava, utemeljenja međunarodnog prava, osude zločina protiv čovječnosti (Derrida, États d'âme de la psychanalyse 63), kao i one koje se tiču, pogotovo u Europi, suvereniteta država, napuštanja suvereniteta, harmonizacije legislativa itd. (Derrida, États d'âme de la psychanalyse 48).

Po čemu je onda, unutar tih simetričnih, pozitivnih i negativnih preobrazbi, u širokom, neograničenom polju stvarnosti suvremenog svijeta, psihoanaliza pozvana kao posljednja instanca tumačenja? Koji to izazov danas stoji pred psihoanalizom, usred tih „okrutnih preobrazbi okrutnosti“, nakon čuvenog Einsteinova pisma Freudu i tri pitanja koja su već anticipirala sljedeći njegov odgovor: „mi smo u psihoanalizi nakon mnogih lutanja i kolebanja“ došli do uvida da u čovjeku postoje „nagoni koji teže razaranju i ubijanju; njih smo sabrali pod imenom nagona za agresijom ili destruktivnog nagona" (Freud, Budućnost jedne iluzije 373). U čemu je sada novi veliki izazov, kada to odavno nije pitanje: „Zašto rat? Ili pak: „Otkud okrutnost?“ 


\section{S onu stranu psihoanalize same}

Na prokrčenom putu k okrutnosti sama psihoanaliza postaje psihoanaliza okrutnosti po svome temeljnom određenju. ${ }^{15} \mathrm{Da}$ bi se to uvidjelo trebalo bi odmjeriti učinke i posljedice na samu psihoanalizu onog odlučnog koraka koji je poduzeo Freud u svome spisu S onu stranu principa ugode. Derridaino shvaćanje psihoanalitičke revolucije koja bi tek trebala doći svoju najvažniju objavu nalazi u ovom djelu metapsihološke spekulacije, čiji se učinci i posljedice u stvari pokazuju nemjerljivim. Ali i uglavnom neprihvatljivim, kako to pokazuju silni otpori u samoj psihoanalizi od nastanka tog spisa pa do danas. Ti su otpori prije svega pokušaji zaustavljanja Freuda u odbacivanju njegovih vlastitih teza:

U čitanju $S$ onu stranu principa ugode, koje nije bilo kakva Freudova knjiga i, kao što znate, nije bilo kakva Freudova knjiga za Lacana, nastojao sam da naznačim po kojem osnovu to Freud napreduje tako što bez zadržavanja suspendira sve one teze kod kojih bi ga njegovi sljedbenici ili nasljednici, njegovi čitatelji uopće, imali interesa zaustaviti. (Derrida, Résistances de la psychanalyse 59)

Nije to bio nekakav dopunski korak za psihoanalizu, uvođenje još jednog nagona ili reinterpretacija ranije priznatih nagona (tzv. ja-nagona), nego radikalni čin transgresije, čak s onu stranu psihoanalize same. Taj spekulativni proboj može se čitati i kao Freudovo odvažno otvaranje k onom konceptu nesvjesnog kako ga je Derrida skicirao još u svom programskom tekstu La différance, na onom mjestu gdje upravo komentira taj Freudov spis. Tamo se uvođenje nagona smrti tumači kao prihvaćanje „radikalne drugosti u odnosu na svaki mogući modus prisustva“, kao „nepopravljivi gubitak prisutnosti“, što onda otvara put shvaćanju nesvjesnog koje izmiče raspoloživim metafizičkim kategorijama prema kojima je ono „skriveno, virtualno, potencijalno prisustvo pri sebi“. Umjesto da bude „nešto“, neka „stvar“, nesvjesno se ukazuje kao neprekidno „tkanje razlika/odgoda": il se diffère (Derrida, La différance 60-61). A sada, u predavanju tridesetak godina kasnije, upletena u prinudi ponavljanja iza koje stoji nagon smrti (Trumbull 73-76), a možda čak i poistovjećena s tom prinudom reinterpretiranom u ključu archi-écriture, ${ }^{16}$ sama okrutnost - kao termin koji nema

\footnotetext{
15 „To bi podrazumijevalo psihoanalizu preobraženu od vrha do dna okrutnošću koja sačinjava njezin 'vlastiti' predmet“ (Wortham 129). „Psihoanaliza je postala kraljevski put ka psihičkoj okrutnosti“" (Rottenberg, Cruelty and Its Vicissitudes 154).

${ }^{16}$ „Nesvjesno bi za Derridau bila rezerva ponavljanja - iterabilnosti - koja čini da neki događaj nastu-
} 
svog „suprotnog termina“ (terme contraire), pa je tako s onu stranu svakog uređenog polja binarnih opozicija, tj. bez kraja naprosto (terme tout court) (Derrida, États d'âme de la psychanalyse 12) - postaje istoznačna s „tkanjem razlika/ odgoda“. Ne čudi onda da za „statutarnu i ovlaštenu psihoanalizu“ taj termin mora ostati zbrkan i opskuran, jer ,ima samo razlika okrutnosti, razlika modaliteta, kvaliteta, intenziteta, aktivnosti ili reaktivnosti u jednoj istoj okrutnosti“ (Derrida, États d'âme de la psychanalyse 73). Tu onostranost nesvjesnog i okrutnosti psihoanaliza, dakle, još ne može misliti bez velikih otpora, jer to pretpostavlja podvrgavanje svih njezinih najvažnijih pojmova radu dekonstrukcije.

Međutim, da bi mogli vidjeti nadolazeću psihoanalitičku revoluciju kao političku (pa onda i društvenu, etičku, pravnu itd.), trebamo dokučiti oko kojeg se principa u samom polju političkog, kao državno-pravno političkog, okrutnost događa i kao legitiman nalog vlasti izvršava. Za Derridu nema sumnje da je to princip državno-pravnog suvereniteta. No, što bi psihoanalitički diskurs uopće imao sa suverenitetom? Na koji bi se način psihoanaliza mogla pokazati revolucionarnom u rušenju tog principa?

Po tome što taj princip ima svoje duboko i neiskorjenjivo utemeljenje u nesvjesnom: u nagonu smrti, ali i u nagonu za moći (Bemächtigungstrieb) za koji će Derrida primijetiti da također „ima svoje izvorno mjesto u $S$ onu stranu principa ugode“ (Derrida, États d’âme de la psychanalyse 35) (usp. također Derrida, La carte postale 430). Nikakva se "progresivistička politika“ ne može suočiti s okrutnošću, zalagati za njezino uklanjanje iz ljudske povijesti, bez pozivanja na znanje psihoanalize (pa je u tom smislu paradigmatično Einsteinovo obraćanje Freudu). Međutim, upravo se psihoanaliza sa svojim učenjem o nagonima uništenja i moći, a nagon za moći Derrida razumijeva kao nagon suvereniteta, može pojaviti kao najvǎnija i posljednja obrana principa državnog suvereniteta. No, da bi takvu političku ulogu doista mogla na sebe preuzeti, ona bi se morala vratiti nekoliko koraka unazad od onog mjesta do kojeg je na kraju došao Freud, trasirajući put s onu stranu i principa ugode i principa zbilje, a to znači, na primjer, regredirati na ego - psihologiju - zato što princip suvereniteta podrazumijeva suverenog subjekta (okrutnosti). Taj otpor unutar same psihoanalize u novije vrijeme prati otpor izvan psihoanalize, koji Derrida označava kao tendenciju 
zaborava psihoanalize u ime - da kažemo u političkim terminima - reakcionarne restauracije kraljevstva subjekta iz doba prije psihoanalitičke revolucije. ${ }^{17}$

Nema sumnje da je za „većinski i statutarni psihoanalitički diskurs“ svako vezivanje nagona smrti s pitanjima suvereniteta države principijelno riskantno prekoračenje i da može voditi k opasnoj politizaciji psihoanalize. Derrida je, međutim, uvjeren $\mathrm{u}$ „neraskidivu vezu okrutnosti sa suverenitetom države, $\mathrm{s}$ nasiljem države, $s$ državom koja, daleko od toga da se suprotstavlja nasilju, njega monopolizira" (Derrida, États d’âme de la psychanalyse 66), o čemu rječito svjedoče njegovi posljednji seminari o smrtnoj kazni. On se poziva na ono što bi mogla biti Freudova politika, koju vidi skiciranu u Freudovu pismu Einsteinu, primjećujući da „uvijek oko riječi 'okrutnost' i smisla okrutnosti Freudova argumentacija postaje više politička i, u svojoj logici, strože psihoanalitička" (Derrida, États d'âme de la psychanalyse 69). Spomenuti jedan jedini put, tek započeti i jedva utrti put psihoanalize, čija je zvijezda vodilja pitanje okrutnosti, podrazumijeva taj iskorak u politiku, koji, dakako, legitimira i „izvanjsku“ poziciju tog „prijatelja psihoanalize“. Za Derridu je zato jednako važno što u ovom proširenju granica psihoanalize na uzorit način sudjeluju i neki opunomoćeni psihoanalitičari, pri čemu posebno izdvaja Élisabeth Roudinesco i Renéa Majora („u njihovim etičko-političko-institucionalnim zalaganjima, u njihovim afinitetima i konfliktima koji ih određuju, s ovu i s onu stranu psihoanalitičkih zajednica u Francuskoj i izvan Francuske) (Derrida, États d'âme de la psychanalyse 58). Može se čak ukazati na postojanje čitave jedne deridijanske struje među psihoanalitičarima (Cabestan 63).

${ }_{17}$ „Ono što se zbiva u filozofiji, a predstavlja opći trend, riskiram li da ga na masivan i makroskopski način okarakteriziram, jeste to da su nakon jednog momenta zastrašujuće zebnje izvjesni filozofi došli sebi. Pa se danas, u duhu vremena, počinju praviti kao da ničeg nije bilo, kao da se ništa nije dogodilo, kao da uzimanje u obzir događaja psihoanalize, logike nesvjesnog, čak „nesvjesnih pojmova", nije bilo ni na koji način obvezujuće, nije čak imalo mjesta u nečemu kao što je povijest uma; kao da bi se moglo mirno nastaviti sa starim dobrim diskursom prosvjetiteljstva, vratiti Kantu, pozivati na etičku i pravnu ili političku odgovornost subjekta, obnavljajući autoritet svijesti, jastva, refleksivnog cogita, nekog 'ja mislim' bez muke i bez paradoksa; kao da je u ovom momentu filozofske restauracije koja je u duhu vremena - jer ono što je na dnevnom redu, što je moralni nalog na dnevnom redu, upravo je neka vrsta sramežljive i sklepane restauracije - kao da se, dakle, radilo o tomu da se uredno poslože spomenuti zahtjevi uma u diskursu koji je čisto komunikacijski, informacijski i bez nabora; kao da je, eto napokon, ponovo postalo legitimno optuživati za mračnjaštvo i iracionalizam svakog tko imalo komplicira stvari pitajući se o umnosti uma, o povijesti principa uma ili o događaju, možda traumatičnom, a što nešto kao psihoanaliza predstavlja u odnosu uma prema sebi." (Derrida, Let us not forget - Psychoanalysis, ovdje prevedeno s francuskog prema navodu Major, Derrida, lecteur de Freud et de Lacan 166) 
Upravo suočavanje psihoanalize s okrutnošću suverena, princa, onog tko utjelovljuje princip suvereniteta, princip tout court, stavlja na probu njezinu pozvanost da bude jedini diskurs na koji se može računati s onu stranu principa suvereniteta. Ako se suverenitet u bitnom smislu definira preko subjekta, kao „autonomija i svemoć subjekta - individualnog i državnog subjekta - slobode, egologijske volje, svjesne intencionalnosti, ako hoćete, jastva, ideala ja i nad-ja itd.“, onda psihoanaliza, kakvom ju vidi njezin „prijatelj“, postaje najpozvanija za pitanje suvereniteta, postavljeno na najradikalniji način, a to znači kao pitanje „izvjesne onto-teološke metafizike suvereniteta“ (Derrida, États d'âme de la psychanalyse 19).

Freudova politika, ili politika koja bi se mogla obrazovati polazeći od njegovih šturih naznaka kako izaći nakraj s nagonom smrti i okrutnosti u ime „vječnog mora", podrazumijeva aksiom o neiskorjenjivosti tog nagona. Ako je vjerovanje u konačno uklanjanje ljudske okrutnosti bilo česta iluzija humanističke ili progresivističke politike, poput one „boljševičke“ na koju se poziva otac psihoanalize, ${ }^{18}$ onda je sada riječ o politici bez iluzija. Po svome bitnom određenju ta je politika u stvari politika kultiviranja, tj. pripitomljavanja nagonskog života čovjeka kroz „napredujuće pomicanje nagonskih ciljeva i ograničavanje nagonskih pobuda“, a njezinu slabašnu mogućnost tek jamči manjina onih koji kao pacifisti, među koje Freud ubraja i samoga sebe, imaju „konstitucionalnu intoleraciju“ prema ratu (Freud 378). Tu politiku, okrenutu „pregovaranju, indirektnom nagađanju“ s nagonima agresivnosti, Derrida će označiti kao „ujedno optimističnu i pesimističnu, odvažno razuvjerenu, odlučno otriježnjenu“ (États d'âme de la psychanalyse 37).

Međutim, onog trenutka kada se psihoanaliza pojavi kao izvjesna „progresivistička politika“ ili, radije, kada njezino znanje postane temelj takve politike, tu su odmah pored politike u igri i etika i pravo i ekonomija itd. Iz motrišta same psihoanalize sada može postati problematično to „izvanjsko“ povezivanje. Derrida to pokušava riješiti konceptom artikulacije, koji „pretpostavlja vezu i razdvojenost“ (États d’âme de la psychanalyse 71) ${ }^{19}$ ili odnos čija je "posljedica indirektna i diskontinuirana“: „psihoanaliza kao takva ne producira ili ne pribavlja nikakvu etiku, nikakvo pravo, nikakvu politiku, dakako, ali se tiče odgo-

\footnotetext{
${ }^{18}$ Međutim, kako napominje Freud, „iluzija nije isto što i zabluda; ona i nije nužno zabluda“ (Freud 339).

${ }^{19}$ Derrida ovdje očito preuzima Saussureov obrazac artikulacije, kao vezu označitelja i označenog u articulusu (de Saussure 156).
} 
vornosti, u sve tri domene, da se uzme u obzir psihoanalitičko znanje“" (Derrida, États d’âme de la psychanalyse 77). Pozivajući se ponovo na spomenuto Freudovo pismo, Derrida će naglasiti da: „Psihoanaliza kao takva ne treba vrednovati ili lišiti vrijednosti, diskreditirati okrutnost ili suverenitet $s$ nekog etičkog gledišta. (...) Bilo da se radi o nagonu okrutnosti ili suvereniteta, psihoanalitičko znanje kao takvo nema nikakvog načina niti prava da ih osudi“ (Derrida, États d'âme de la psychanalyse 76-77).

Ta artikulacija za koju se zalaže Derrida u svome predavanju iz 2000. godine, tada kao i danas, i dalje stoji kao neispunjeno obećanje ili čak kao neostvariva mogućnost. Kao da se ništa nije promijenilo od njegova uvodnog predavanja iz davne 1981. godine kada je govorio o općem stanju „apsolutne disocijacije između sfere psihoanalitičkog i sfere građanina ili moralnog subjekta u njegovu javnom ili privatnom životu“. ${ }^{20}$ I dalje ovaj „prijatelj psihoanalize“ na sebe preuzima odgovornost - iako, kako priznaje, ne može polagati pravo na odgovornost psihoanalitičara niti snositi posljedice za svoju neodgovornost pred psihoanalitičarima - da gotovo usamljeničkim glasom pledira za „nužnost nove etike, ne samo etike psihoanalize, koja ne postoji, nego drugog etičkog diskursa o etici uopće, drugog političkog diskursa o politici uopće, diskursa koji bi vodio računa o moćnom dekonstruktivističkom i psihoanalitičkom pokretaču, diskursa koji bi vodio računa, ako je moguće, o onom što se tumači kao istina psihoanalize“ (Derrida, Psyché 344). ${ }^{21}$

${ }^{20}$ Tada je, možda s manje opreza, govorio o međusobnoj integraciji, a ne o artikulaciji, ipak napominjući da ona „ne bi bila mirna aproprijacija, da ne bi išla bez deformacija i transformacija s obje strane.“ Tamo također čitamo: „Usprkos svoj uzavrelosti oko pitanja tipa 'psihoanaliza i politika', usprkos umnožavanju rasprava koje se u tu svrhu vode već najmanje deset ili dvanaest godina, svakako treba priznati - što je o svemu tome čak i znak - da danas ne postoji političke problematike ili koda političkog diskursa koji je u sebi integrirao, na strog način, aksiomatiku moguće psihoanalize, ako je ta psihoanaliza moguća. Moja je hipoteza da se, dakle, takva integracija nije dogodila. Kao što nijedan etički diskurs nije integrirao aksiomatiku psihoanalize, tako nijedan politički diskurs to nije učinio." (Derrida, Psyché 339)

${ }^{21}$ Preuzimajući na sebe ulogu stranca, stranog tijela pa i simptoma među okupljenim psihoanalitičarima, Derrida će ići dotle da izjavi: „Ja sam psihoanalitički neodgovoran i možda upravo zato što su neke stvari rečene iz usta jednog neodgovornog lica da me se ovdje i dovelo. Neću morati odgovarati za ono što kažem pred pariškom, nacionalnom ili internacionalnom analitičkom instancom. “ (Derrida, Psyché 331) 


\section{Zaključak}

Iako je Derrida od svojih prvih radova svoje mišljenje vezao uz psihoanali$\mathrm{zu}$, on se tek kasno, kao što primjećuje Ryder, upustio u „razmatranje njezina značaja za politička pitanja“ (125). Ta je pitanja najiscrpnije otvorio upravo u svome predavanju psihoanalitičarima na skupu Etats Généraux de la Psychanalyse, pozivajući se na naznake iz spisa kasnoga Freuda. Slijediti oca psihoanalize na ovome tek otvorenom putu za Derridu je značilo upustiti se u ponornu dimenziju „s onu stranu“ same psihoanalize, budući da je Freudova metapsihološka spekulacija s nagonom smrti i okrutnosti dovela u pitanje vladavinu i principa ugode i principa zbilje. Međutim, Freudova spekulativna transgresija s onu stranu dotada vladajućih principa psihoanalize, u samoj toj „onostranosti“ utemeljuje novi princip koji prije svega treba shvatiti kao princip suverenosti, iza kojeg stoji - svejedno kako ćemo ga imenovati ili hoćemo li ga uzeti kao jedan ili više njih - nagon smrti, nagon za moći ili nagon suverenosti. S tim se principom više, barem u samoj psihoanalizi, ne može povući ili održati razlika između nagonskog i političkog, između nesvjesnog i državno-pravnog. Pod vladavinom tog principa ne postoji ništa što je s onu stranu okrutnosti, osim što se može tek uvjetno utvrditi nejasna i mutna razlika između „psihičke okrutnosti“ i „krvave okrutnosti“.

Međutim, Derrida je uvjeren da Freuda također treba slijediti u njegovoj „progresivističkoj“ politici, u njegovu prosvjetiteljskom opredjeljenju i težnji k ostvarenju ideala „vječnog mira“. Zato bi psihoanaliza, jer jedino se od nje to može očekivati, a što bi ju učinilo uistinu revolucionarnom, trebala napraviti još jedan korak više u odnosu na kasnog Freuda - korak koji bi, dakle, išao s onu stranu nagona smrti ili principa državno-pravnog suvereniteta. Takav pothvat Derrida definira kao „s onu stranu s one strane“ (l’au-delà de l'au-delà) (Derrida, États d'âme de la psychanalyse 83). Otvaranje obzora te druge „onostranosti“ ostaje zagonetno i ničim osigurano - Derrida će čak ustvrditi: nemoguće - budući da se nipošto ne može dovesti u pitanje Freudov aksiom o neiskorjenjivosti nagona smrti ili okrutnosti. Međutim, dekonstruktivistički osviještena psihoanaliza raspolaže drugim sredstvima ili, radije, strategijama, osim, u ovom slučaju, neizvedivog negiranja, ukidanja ili prevladavanja (Aufhebung), s kojima raspolaže metafizička tradicija. Kada Freud u svome pismu Einsteinu govori o izlaženju nakraj s ljudskom okrutnošću, upućujući na mogućnosti odgode, zaobilaženja, preusmjeravanja, mehanizama identifikacije itd., čini se da on već upotrebljava vokabular dekonstrukcije. Kada na kraju svog predavanja Derrida 
za namjeravani proboj „s onu stranu s one strane“ uvodi referencu na „ono bezuvjetno, bezuvjetno bez suvereniteta, pa tako i okrutnosti“ (Derrida, États d'âme de la psychanalyse 82), smjelo ga označujući kao „ono nemoguće bezuvjetno“, koje je „bez sumnje teško za promišljati“, onda to nije izrečeno sa sviješću o bezizlaznosti. To "ne-moguće (im-possible) koje ne bi bilo naprosto negativno“ (Derrida, The 'World' of the Enlightenment 34) u mišljenju je dekonstrukcije već istraživano i iskušano u „brojnim figurama onog nemoguće bezuvjetnog“: „gostoprimstvo, dar, oprost - i ponajprije nepredvidljivost, ono 'možda', ono 'i ako' događaja, dolazak i dolazak drugoga uopće, njegovo pristizanje“ (Derrida, États d'âme de la psychanalyse 83).

Tako neka psihoanaliza, koja nosi obećanje svoje dekonstrukcije, izravno ulazi u širi obzor dekonstruktivističke političke filozofije koja sebe odavno traži u ključu demokracije à venir. ${ }^{22}$ Kada Esther Hutfless govori o psihoanalizi koju Derrida ima u vidu, kao o psychoanalysis to come, ona se poziva na ono što je o njoj već naslućeno u njegovu predavanju na Sorboni iz 2000. godine. Nije li upravo promišljanje okrutnosti more psychanalytico posvuda otkrilo nemoguću bezuvjetnost u revolucionarnom očekivanju: demokraciju à venir, prosvjetiteljstvo à venir, čak neki „novi humanizam“? Što može uvjerljivije ukazivati na njihovu suštinsku nemogućnost nego nemoć psihoanalize da, za razliku od „svih filozofija, metafizika, teologija i humanističkih znanosti“, sebi priskrbi bilo kakav „teleološki ili humanistički alibi“? Ne čudi onda da se psihoanaliza ukazuje „Zastrašujućom, užasno okrutnom, nemilosrdnom“ (Derrida, De quoi demain: dialogue 281).

\section{Literatura}

Adorno, Theodor W. Minima Moralia. Reflexionen aus dem beschädigten Leben. Suhrkamp Verlag, 1984.

Bennington, Geoffrey. Interrupting Derrida, Routledge, 2000.

---. and Jacques Derrida, Jacques Derrida. Éditions du Seuil, 1991.

\footnotetext{
${ }^{22}$ Izraz „à venir“ je idiomatski, pa stoga teško prevodiv, nesvodivo višeznačan: demokracija „u na/ dolasku“, „dolazeća“, „upravo dolazeća“, „može biti dolazeća“, „koja bi mogla doći“, „koja /tek/ treba/ima doći“ itd. Izdvajamo kratko autorovo pojašnjenje: „Upravo je to ono što sam želio iznijeti izrazom 'demokracija koja tek treba doći' (la démocratie à venir). 'Demokracija koja tek treba doći' ne znači neku buduću demokraciju koja će jednog dana biti 'sadašnja'. Demokracija nikad neće postojati u sadašnjosti; ona se ne može osadašnjiti i ona nije regulativna ideja u kantovskom smislu. No postoji ono nemoguće, čije obećanje zapisuje demokracija..." (Derrida, Razgovor sa Jacquesom Derridaom 124).
} 
Birnbaum, Jean. „1930-2004, Jacques Derrida - Un ami redoutable de la psychanalyse“, Le Monde, le 12 octobre 2004, https://www.lemonde.fr/archives/article/2004/10/12/ p-1930-2004-p-p-jacques-derrida-p-p-un-ami-redoutable-de-la-psychanalyse-p_4305607_1819218.html. Pristupljeno 21. kolovoza 2020.

Cabestan, Philippe. „Spectres de Freud: Derrida et la psychanalyse.“ Revue de métaphysique et de morale, sv. 53, br. 1, 2007, str. 61-71.

Décarie, Isabelle. „Pouvoirs de la psychanalyse / États généraux de la psychanalyse, sous la direction de René Major, Aubier, 2003." Spirale, br. 197, 2004, str. 48-49.Delaisi de Parseval, Geneviève. „Notes de lectures. De quoi demain: dialogue.“ Le Carnet PSY, La Revue, N 67, 2001, 16. http://www.carnetpsy.com/article.php?id=704\&PHPSESSID=0veha2r725sqnotilavbv8pn25. Pristupljeno 21. kolovoza 2020.

Derrida, Jacques. „Freud et la scène de l'écriture.“ Lécriture et la différence. Éditions du Seuil, 1967.

---. „La différance“. Tel Quel: Théorie d'ensemble - choix. Éditions du Seuil, 1968, str. 43-68.

---. $\quad$ De la Grammatologie. Éditions de Minuit, 1969.

---. Positions. Éditions de Minuit, 1972.

---. La carte postale de Socrate à Freud et au-delà. Aubier-Flammarion, 1980.

---. De l'esprit : Heidegger et la question. Éditions Galilée, 1987.

---. Psyché. Inventions de l'autre. Éditions Galilée, 1998.

---. Fidélité à plus d'un.“ Idiomes, nationalités, déconstructions. Intersignes et les éditions Toubkal, 1998, str. 221-265.

---. „Let us not forget - Psychoanalysis.“ The Oxford Literary Review, sv. XII, br. 1-2, 1990, str. 3-8.

---. Résistances de la psychanalyse. Éditions Galilée, 1996.

---. États d'âme de la psychanalyse. L'impossible au-delà d'une souveraine crauté. Galilée, 2000.

---. $\quad$ et Roudinesco, Élisabeth. De quoi demain: dialogue. Fayard/Galilée, 2001.

---. „The 'World' of the Enlightenment to Come (Exception, Calculation, and Sovereignty)". Research in Phenomenology, br. 33, 2003, str. 9-52.

--- . Learning to Live Finally. The Last Interview. Palgrave Macmillan, 2007.

---. „Razgovor sa Jacquesom Derridaom,“ Preveo Davor Stipetić, Politička misao, sv. 46, br. 3, 2009, str. 91-138.

Freud, Sigmund. Budućnost jedne iluzije Preveo Boris Buden, Naprijed, 1986.

---. $\quad$ und Ferenczi, Sándor. Briefwechsel. Band III/2, 1925-1933, Hrsg. von Ernst Falzeder und Eva Brabant, Böhlau Verlag, 2005.

Huber, Gérard. Anatomie de la séparation. Réponses à Jacques Derrida. De Boeck Supérieur, 2002 . 
Hutfless, Esther. „Psychoanalysis to Come: A 'Freuderridian' Approach to a Non-normative Psychoanalysis." The Undecidable Unconscious: A Journal of Deconstruction and Psychoanalysis, sv. 6, 2019, str. 1-27.

Lacour, Philippe. „René Major (dir.), États généraux de la psychanalyse.“ Labyrinthe, br. 17, 2004, str. 119-21.

Laplanche, Jean. Essays On Otherness. Routledge, 1999.

Major, René. Appel pour les États Généraux de la Psychanalyse, 1997. http://www.psicomundo.com/foros/egp/appel.htm. Pristupljeno 21. kolovoza 2020.

---. Derrida, lecteur de Freud et de Lacan.“ Études françaises, sv. 38, br. 1-2, 2002, str. 165-78.

---. „Il aura [encore] parlé en nous avant nous.“ Salut à Jacques Derrida, Collège international de philosophie, PUF, 2005.

Rottenberg, Elizabeth. „Cruelty and Its Vicissitudes: Jacques Derrida and the Future of Psychoanalysis." The Southern Journal of Philosophy, sv. 50, Spindel Supplement, 2012, str. 143-59.

Rottenberg, Elizabeth. „Derrida and Psychoanalysis.“ A Companion to Derrida, uredili Zeynep Direk i Leonard Lawlor, Wiley \& Sons, Ltd., 2014, str. 304-20.

Ryder, Andrew. „Politics after the Death of the Father: Democracy in Freud and Derrida.“ Mosaic, sv. 44, br. 3, 2011, str. 115-31.

Saussure, Ferdinand de. Cours de linguistique générale. Payot, 1971.

Trumbull, Robert. „Deconstruction and Psychoanalysis:'A Problematic Proximity”. Derrida Today 5.1, Edinburgh UP, 2012, str. 69-91.

Wortham, Simon. Modern Thought in Pain. Philosophy, Politics, Psychoanalysis. Edinburgh UP, 2015. 


\title{
BEYOND CRUELTY. A FRIGHTENING FRIEND OF TERRIFYING PSYCHOANALYSIS
}

\begin{abstract}

\section{UGO VLAISAVLJEVIĆ}

University of Sarajevo

Faculty of Humanities and Social Sciences

Franje Račkog 1

$\mathrm{BiH}-71000$ Sarajevo

vlaisugo5@gmail.com
\end{abstract}

The article proposes a close reading of Jacques Derrida's address to the Estates General of Psychoanalysis, held in Paris in July 2000. In celebrating the centenary of Freud's Interpretation of Dreams, the representative international gathering of psychoanalysts took place under the umbrella of a "political metaphor" suggested by its historically significant title and dates. In Derrida's address, the metaphor of revolution was far more than just a bright emblem of the meeting, expressing the organizers' wish to emphasize the revolutionary character of Freud's "invention" or to encourage the participants' enthusiasm for solving the current crisis of their profession in the manner inspired by the Estates General in 1789. It is only in his late work, and particularly in this introductory lecture dealing with human cruelty and its recent historical mutations, that Derrida began to explore the deconstructive political potentialities of psychoanalysis. His hypothesis on the superiority of psychoanalysis over all other discourses in dealing with this highly political issue assumes that there is, although not yet fully recognized, or even strongly opposed, a politics inherent to Freud's theory. Outlined in his later writings, Freud's "progressive politics," already engaged in a subversion of the principle of state sovereignty, as proved to be able to indicate a strategy of going "beyond the death drive," calls for creating a new, revolutionary psychoanalysis beyond all principles. The article attempts to reveal that Derrida's politically oriented reading of Freud's legacy crucially depends on his unique position of "the friend of psychoanalysis."

Keywords: cruelty, friend of psychoanalysis, death drive, principle of sovereignty, revolution 